\title{
Evaluation of Temperature Prediction Methods for Mass Concrete Members
}

\author{
by Kyle A. Riding, Jonathan L. Poole, Anton K. Schindler, Maria C. G. Juenger, \\ and Kevin J. Folliard
}

Over the years, many different simplified prediction methods have been developed to predict the temperature development within mass concrete members. This paper compares calculated temperature values from three commonly-used concrete temperature prediction methods to actual temperatures in eight different concrete bridge members measured during construction. A simple temperature calculation method, the graphical method of ACI 207.2R, and a numerical heat transfer method (the Schmidt Method) were used to predict peak temperatures. The Schmidt Method performed the best when semi-adiabatic calorimetry results were used in the analysis. Suggestions are made on ways to improve the best technique, which was the Schmidt Method.

Keywords: heat; mass concrete, temperature.

\section{INTRODUCTION}

Cement hydration is an exothermic reaction capable of generating large amounts of heat. The core of mass concrete members can become very hot unless internal cooling or low-heat-producing materials are used. This has historically been a problem in dams, and numerical methods of predicting temperatures throughout mass concrete elements have been available since the 1920s. The current state of the practice in dams is to perform adiabatic calorimetry testing on concrete mixtures and use finite element analysis to predict temperature distributions over time.

Until recently, it was assumed that high temperatures were not a problem in bridge substructure members, and that this problem was unique to dams and precast concrete. In recent years, however, bridge substructure members have become larger because of new construction methods and aesthetic interests. At the same time, cement fineness and cement content in concrete have increased, raising the concrete's adiabatic temperature. As a consequence, there is increased concern over thermal cracking in bridge substructure members, long-term decrease in strength, and delayed ettringite formation (DEF) (a mechanism that causes cracking in concrete when ettringite formation is delayed by high temperatures). ${ }^{1}$ In response to a survey conducted in 2003, nine state highway agencies (SHAs) had mass concrete specifications and eight states had mass concrete special provisions. Seven of the states with mass concrete specifications limit the maximum concrete temperature difference to $20{ }^{\circ} \mathrm{C}\left(35{ }^{\circ} \mathrm{F}\right)$, and two states limit the maximum in-place temperature to $71^{\circ} \mathrm{C}\left(160^{\circ} \mathrm{F}\right)$. Six of the eight states with mass concrete special provisions have maximum concrete temperature difference limits, and three have maximum in-place temperature limits. ${ }^{2}$

The Texas Department of Transportation (TxDOT) Specification $420,{ }^{3}$ for example, defines mass concrete as any member having a least dimension of $1.5 \mathrm{~m}(5 \mathrm{ft})$, or as designated by the engineer. Many bridge substructure components in Texas now meet that definition. TxDOT Specification 420 limits mass concrete placement temperature to $24{ }^{\circ} \mathrm{C}\left(75^{\circ} \mathrm{F}\right)$, the maximum in-place temperature to $71{ }^{\circ} \mathrm{C}\left(160{ }^{\circ} \mathrm{F}\right)$ (to avoid DEF), and the maximum temperature difference in the concrete to $20^{\circ} \mathrm{C}\left(35^{\circ} \mathrm{F}\right)$. Contractors are required to submit a temperature control plan for mass concrete before construction begins. All concrete temperature prediction calculations in the temperature control plan must be made using the methods described in Portland Cement Association's (PCA) Design and Control of Concrete Mixtures, ${ }^{4}$ or using the Schmidt Method as described in the American Concrete Institute's ACI 207.1R. ${ }^{5}$ The measurement of temperatures at two separate locations is also required. If the concrete temperature exceeds any of the specifications, adjustments to the temperature control plan are required to ensure compliance with the specification.

Contractors need quick, simple, accurate, up-to-date methods or software to evaluate the impact of different viable options for temperature control and to develop their temperature control plans. Several methods, such as the Schmidt Method, have been used successfully over the years to calculate the temperature rise in very large mass concrete members. ${ }^{5}$ For these large mass concrete members, the maximum temperature of the concrete is primarily a function of the concrete's adiabatic temperature rise potential. In smaller mass concrete bridge members, the maximum temperature is a function of the adiabatic temperature development and heat transfer with the environment.

This paper evaluates the ability of the two temperature prediction methods allowed by TxDOT (which we will refer to as the PCA Method and the Schmidt Method), as well as the graphical method described in ACI 207.2R, ${ }^{6}$ Section 2, to predict the maximum temperature in smaller mass concrete bridge members. The predicted maximum temperature from each method will be compared against actual temperature data from mass concrete bridge members recently constructed in Texas. Various concrete members were selected for temperature instrumentation based on their location, environmental exposure condition, size, formwork used, mixture proportions, and shape. Two columns, two footings, one pedestal, one dolphin (a mass concrete structure that protects bridges from ship impact), one rectangular bent cap, and one T-shaped bent cap were instrumented.

ACI Materials Journal, V. 103, No. 5, September-October 2006

MS No. 05-116 received April 20, 2006, and reviewed under Institute publication policies. Copyright (C) 2006, American Concrete Institute. All rights reserved, including the making of copies unless permission is obtained from the copyright proprietors. Pertinent discussion including authors' closure, if any, will be published in the July-August 2007 ACI Materials Journal if the discussion is received by April 1, 2007. 
ACI member Kyle A. Riding is a PhD Candidate at the University of Texas at Austin, Austin, Tex. He received his BS from Brigham Young University, Provo, Utah, and his MS from The University of Texas at Austin.

ACI member Jonathan L. Poole is a PhD Candidate at the University of Texas at Austin. He received his BS and MS from The University of Texas at Austin.

ACI member Anton K. Schindler is an Assistant Professor in the Department of Civil Engineering at Auburn University, Auburn, Ala. He received his MSE and PhD in civil engineering from the University of Texas at Austin. He is a member of ACI Committees 201, Durability of Concrete; 231, Properties of Concrete at Early Ages, 237, Self-Consolidating Concrete; and E 803, Faculty Network Coordinating Committee.

ACI member Maria C. G. Juenger is an Assistant Professor of Civil, Architectural, and Environmental Engineering at The University of Texas at Austin. She received a $P h D$ in materials science and engineering from Northwestern University, Evanston, Ill. She is a member of ACI Committees 201, Durability of Concrete; 236, Material Science of Concrete; and E 802, Teaching Methods and Educational Materials.

Kevin J. Folliard, FACI, is an Associate Professor in the Department of Civil, Architectural, and Environmental Engineering at The University of Texas at Austin. He received his $P h D$ in civil engineering from the University of California at Berkeley, Berkeley, Calif., in 1995. He is a member of ACI Committees 201, Durability of Concrete; 236, Material Science of Concrete; and the ACI Publications Committee. He received the ACI Young Member Award for Professional Achievement in 2002.

\section{RESEARCH SIGNIFICANCE}

The commonly-used temperature prediction methods discussed in this paper were developed over 50 years ago. Construction methods, form types, cement chemistry, cement fineness, supplementary cementing materials (SCMs), and chemical admixtures have changed dramatically since then, suggesting that these methods may no longer be appropriate or may need to be updated. The use of mass concrete members has also increased in recent years, creating a need for accurate temperature prediction. In the research presented herein, the accuracy of three commonly used mass concrete temperature calculation methods is assessed by their ability to predict maximum temperatures in eight actual mass concrete bridge members.

\section{Maximum temperature}

\section{BACKGROUND INFORMATION}

The maximum in-place temperature reached in a mass concrete member can affect the long-term performance of a structure. Studies have shown that plain cement paste cured above $50{ }^{\circ} \mathrm{C}\left(122{ }^{\circ} \mathrm{F}\right)$ can, in the long term, have lower strength, larger pores, and increased permeability. ${ }^{7}$ Delayed ettringite formation (DEF) has also been shown to cause durability problems when concrete is cured at elevated temperatures (for example, temperatures in excess of $70{ }^{\circ} \mathrm{C}$ $\left.\left(158{ }^{\circ} \mathrm{F}\right)\right)$. The rate of temperature increase, duration of the induction period, maximum temperature, and cooling rate are all factors that may determine the extent of damage from DEF. ${ }^{1}$ The time reached and magnitude of the maximum temperature are critical in determining the maximum temperature difference.

\section{Maximum temperature difference}

Large temperature differences can occur when the concrete core is hot and the ambient temperature is low or when the forms are removed when the concrete underneath is hot, typically referred to as "thermal shock." 5 The maximum temperature difference causes a change in volume because of thermal expansion/contraction and can affect thermal cracking in concrete when the member is restrained by adjacent elements or foundations.

The current TxDOT specification 420 is based on guidelines developed for mass concrete projects in Europe during the 1950s. ${ }^{8}$ Gajda and VangGeem ${ }^{8}$ suggest that the maximum allowable temperature differential should increase with the compressive strength. Bamforth and Price ${ }^{9}$ developed the following equation to calculate the maximum allowable temperature differential

$$
\Delta T=\frac{\varepsilon_{t s c}}{K \alpha_{c} R}
$$

where $\Delta T$ is the maximum temperature difference, in ${ }^{\circ} \mathrm{C} ; \varepsilon_{t s c}$ is the tensile strain capacity; $K$ is a modification factor for sustained loading and creep; $\alpha_{c}$ is the coefficient of thermal expansion of the maturing concrete $\left(1 /{ }^{\circ} \mathrm{C}\right)$; and $R$ is the restraint factor. Aggregate type, cement content, supplementary cementing materials, amount of reinforcement, and reinforcement detailing will all alter the temperature difference that will cause thermal cracking. ${ }^{9-11}$ Concrete properties, such as the coefficient of thermal expansion, tensile strength, and modulus of elasticity, are all time- and temperature-dependent and, thus, may affect the concrete's cracking susceptibility as the concrete matures.

Several researchers have found that simple, temperaturedifference-based specifications are unreliable for controlling thermal cracking in concrete elements. ${ }^{12-14}$ The tensile strength of the concrete is also a function of the concrete's maturity. The thermal gradient required to produce cracking is consequently also a function of the concrete's maturity. Temperature-based specifications fail to take into account the intrinsic stresses that can develop. Residual stresses at the concrete surface are less pronounced when the surface is cooled at a very young age for a sufficient period of time. ${ }^{15}$ This means that a concrete member could, in some circumstances, have a low risk of cracking while at the same time have a high temperature difference, if the large temperature difference occurs at a late age. The temperature development during the first day is typically the most critical parameter in determining the thermal cracking risk. ${ }^{13,15}$

\section{PCA Method}

The Portland Cement Association's (PCA) Design and Control of Concrete Mixtures ${ }^{4}$ gives a quick method for estimating the maximum temperature developed in mass concrete members. This method will be referred to in this paper as the "PCA Method." This method calculates the maximum temperature rise above the concrete placement temperature, as $12{ }^{\circ} \mathrm{C}\left(21.6^{\circ} \mathrm{F}\right)$ for every $100 \mathrm{~kg}(220.4 \mathrm{lb})$ of cement. The PCA Method is only appropriate for concrete containing between 300 and $600 \mathrm{~kg}$ of cement per cubic meter (506 and $1012 \mathrm{lb}$ per cubic yard) of concrete and assumes that the least dimension of the concrete member is at least $1.8 \mathrm{~m}(6 \mathrm{ft}){ }^{4}$ The PCA Method provides no information on time of maximum temperature and does not allow the quantification of temperature differences. The PCA Method treats all ASTM C $150^{16}$ Type I cements the same and gives no guidelines on how to account for slag cement. ACI Committee 207 suggests that modification to account for supplementary cementing materials (SCMs) can be made by presuming that they liberate approximately half the amount of heat of cement for a given mass. ${ }^{5}$ Equation (2) shows the PCA calculation for the maximum concrete temperature $T_{\max }$ when altered to account for the initial placement temperature and SCMs in this manner 


$$
T_{\max }=T_{i}+\left(12 \cdot \frac{W_{c}}{100}\right)+\left(6 \cdot \frac{W_{s c m}}{100}\right)
$$

where $T_{i}$ is the concrete placement temperature, in ${ }^{\circ} \mathrm{C} ; W_{c}$ is the weight of cement, $\mathrm{kg} / \mathrm{m}^{3}$; and $W_{s c m}$ is the weight of supplementary cementing materials, $\mathrm{kg} / \mathrm{m}^{3}{ }^{4}{ }^{4}$ Significant modifications have been made by Bamforth and Price, ${ }^{9}$ who designed charts to correct for member size of less than $2 \mathrm{~m}$ (6.6 ft) (least dimension) and to account for fly ash and slag cement contents. The charts show temperature rise curves per $100 \mathrm{~kg}(220 \mathrm{lb})$ of cementitious materials for different fly ash and slag cement replacement levels as a function of the placement thickness.

\section{Graphical method of $\mathrm{ACl}$ 207.2R}

Section 2 of ACI $207.2 \mathrm{R}^{6}$ contains several charts and equations based on empirical data that can be used to estimate the maximum temperature in mass concrete, hereafter referred to as the "Graphical Method of ACI 207.2R." Adjustments can be made for member size, exposure condition, cement type, use of fly ash and/or slag cement, and placement temperature. The adiabatic temperature rise can be accounted for by Eq. (3).

$$
T_{r}=T_{I} \cdot \frac{T_{f}}{T_{1800}}
$$

where $T_{r}$ is the cement Turbidimeter (ASTM C 115) fineness adjusted adiabatic temperature rise for $171 \mathrm{~kg}(377 \mathrm{lb})$ of cement, in ${ }^{\circ} \mathrm{C} ; T_{I}$ is the adiabatic temperature rise for a Type I cement from ACI 207.2R, Fig. 2.1; $T_{f}$ is the heat generation in percent of 28-day heat generation for the measured cement fineness from ACI 207.2R, Fig. 2.2; and $T_{1800}$ is the heat generation in percent of 28-day heat generation for a cement fineness of $1800 \mathrm{~cm}^{2} / \mathrm{g}\left(6.15 \mathrm{in} .^{2} / \mathrm{lb}\right)$ from ACI 207.2R, Fig. 2.2. ${ }^{6}$ Detailed examples showing the correct use of these charts and equations are given within ACI 207.2R document.

\section{Schmidt Method}

Another method for estimating maximum temperature and maximum temperature differences was developed by E. Schmidt in the 1920s and is summarized in ACI 207.1R. ${ }^{5}$ This method will be referred to in this paper as the "Schmidt Method." It was an important contribution in the precomputer era because the calculations were relatively simple to perform by hand. It was developed as a numerical solution to the Fourier law governing heat transfer, shown in Eq. (4)

$$
\frac{d}{d x}\left(k \cdot \frac{d T}{d x}\right)+\frac{d}{d y}\left(k \cdot \frac{d T}{d y}\right)+Q_{H}=\rho \cdot C_{p} \cdot \frac{d T}{d t}
$$

where $Q_{H}$ is the heat generation term, $\mathrm{W} / \mathrm{m}^{3} ; \rho$ is the density, in $\mathrm{kg} / \mathrm{m}^{3} ; C_{p}$ is the specific heat, in $\mathrm{J} / \mathrm{kg} /{ }^{\circ} \mathrm{C}$; and $T$ is the temperature, in ${ }^{\circ} \mathrm{C}$. The Schmidt Method is a simplified finite difference method. Temperatures are calculated for discrete nodes at discrete time steps. The time step is calculated according to Eq. (5)

$$
\Delta t=\frac{(\Delta x)^{2}}{2 \alpha}
$$

\begin{tabular}{|c|c|c|c|c|c|c|}
\hline \multirow[b]{2}{*}{ Member } & \multicolumn{2}{|c|}{ Placement } & \multirow[b]{2}{*}{$\begin{array}{l}\text { Length, } \\
\text { m (ft) }\end{array}$} & \multirow[b]{2}{*}{$\begin{array}{l}\text { Width, } \\
\text { m (ft) }\end{array}$} & \multirow[b]{2}{*}{$\begin{array}{l}\text { Height, } \\
\mathrm{m}(\mathrm{ft})\end{array}$} & \multirow{2}{*}{$\begin{array}{c}\text { Form- } \\
\text { work } \\
\text { removed, } \\
\text { days }\end{array}$} \\
\hline & $\begin{array}{c}\text { Date } \\
(\mathrm{M} / \mathrm{D} / \mathrm{Y})\end{array}$ & Time & & & & \\
\hline Pedestal & $06 / 11 / 04$ & 10:00 a.m. & $2.9(9.5)$ & $3.2(10.5)$ & $1.7(5.5)$ & $>7$ \\
\hline $\begin{array}{l}\text { T-shaped } \\
\text { bent cap }\end{array}$ & 06/05/04 & 8:00 a.m. & - & $2.2(7.3)$ & $2.5(8.3)$ & 2.25 \\
\hline $\begin{array}{l}\text { Rectangular } \\
\text { bent cap }\end{array}$ & 03/31/04 & 8:00 a.m. & - & $1.0(3.3)$ & $1.0(3.3)$ & 5 \\
\hline Dolphin & $02 / 05 / 04$ & 11:30 a.m. & $4.9(16.0)$ & $4.9(16.0)$ & $2.7(9.0)$ & 5 \\
\hline Footing 1 & $06 / 17 / 03$ & 7:00 a.m. & $7.3(24.0)$ & $7.9(26.0)$ & $2.2(7.3)$ & $>6$ \\
\hline Footing 2 & $08 / 01 / 03$ & 8:00 a.m. & $3.1(10.0)$ & $3.1(10.0)$ & $1.9(6.2)$ & - \\
\hline Column 1 & $06 / 16 / 03$ & 8:00 a.m. & $1.8(6.0)$ & $3.1(10.0)$ & $9.1(30.0)$ & 2 \\
\hline Column 2 & 07/10/03 & 8:00 a.m. & $1.8(6.0)$ & $3.1(10.0)$ & $\begin{array}{c}20.4 \\
(67.0)\end{array}$ & 5 \\
\hline
\end{tabular}

Table 1-Concrete member construction information

where $\alpha$ is the thermal conductivity of the concrete, in $\mathrm{W} / \mathrm{m} /{ }^{\circ} \mathrm{C} ; \Delta t$ is the time step used, in seconds; and $\Delta x$ is the node spacing, in $\mathrm{m}$.

ACI $207.1 \mathrm{R}^{4}$ gives guidance on how to handle boundary conditions using the Schmidt Method, but only for those boundaries next to the bottom surface of the element. For instance, Example 6 given in ACI 207.1R ${ }^{5}$ provides an example of the use of the Schmidt Method using the case of a footing on a rock foundation. The example assigns half of the temperature rise of the concrete under adiabatic temperature conditions, to the bottom surface. A constant rock temperature is usually enforced at a depth, which is assumed to extend a distance equal to one-half of the concrete member height. Insulation is also modeled by using an equivalent concrete thickness. Example 6 also describes the common approach used to account for the heat generation of the cementitious material. The temperature added at each node for each time step is the adiabatic temperature rise for that time, minus the adiabatic temperature rise for the previous time.

\section{Concrete bridge members}

\section{EXPERIMENTAL METHODS}

Eight mass concrete bridge members were instrumented to allow for the comparison of actual and predicted concrete temperatures. The members were selected to obtain a large variety of size, shape, formwork, environmental exposure conditions, constituent materials, and mixture proportions. Table 1 shows the concrete member locations, dimensions, placement information and formwork type. There are several items to note with regard to these members. The dimensions given in Table 1 for the T-shaped bent cap are for the outermost dimensions. The corbel dimensions were $0.65 \times 0.65 \mathrm{~m}$ ( $25 \times 25$ in.). A large quantity of rigid polyurethane foam was used to create an arch on the middle bottom of the T-shaped bent cap. The foam was left in place for several days after removing forms, which reduced the chances of thermal shock. The rectangular and $\mathrm{T}$-shaped bent cap lengths are not listed, but were greater than 20 times the member width or height. To facilitate concrete placement, the bottom two feet of the dolphin was made using precast concrete panels. All three columns were rectangular with $0.15 \times 0.3 \mathrm{~m}(6 \times 12 \mathrm{in}$.) block-outs on the corners for aesthetic purposes. The blockouts were made from plywood. Column 1 had a $203 \mathrm{~mm}$ (8 in.) diameter drainpipe running down the middle. The top of the drain pipe was temporarily sealed during construction to prevent blockage. The rectangular bent cap, T-shaped bent 
Table 2-Concrete mixture proportions and properties

\begin{tabular}{|c|c|c|c|c|c|c|c|c|c|}
\hline \multirow[b]{2}{*}{ Member } & \multicolumn{5}{|c|}{ Proportions } & \multicolumn{4}{|c|}{ Properties } \\
\hline & $\begin{array}{c}\text { Cement, } \\
\mathrm{kg} / \mathrm{m}^{3}\left(\mathrm{lb} / \mathrm{yd}^{3}\right)\end{array}$ & $\begin{array}{c}\text { Fly ash, } \\
\mathrm{kg} / \mathrm{m}^{3}\left(1 \mathrm{lb} / \mathrm{yd}^{3}\right)\end{array}$ & $\begin{array}{c}\text { Water, } \\
\mathrm{kg} / \mathrm{m}^{3}\left(\mathrm{lb} / \mathrm{yd}^{3}\right)\end{array}$ & $\begin{array}{c}\text { Coarse aggregate, } \\
\mathrm{kg} / \mathrm{m}^{3}\left(\mathrm{lb} / \mathrm{yd}^{3}\right)\end{array}$ & $\begin{array}{l}\text { Fine aggregate, } \\
\mathrm{kg} / \mathrm{m}^{3}\left(\mathrm{lb} / \mathrm{yd}^{3}\right)\end{array}$ & $\begin{array}{l}\text { Slump, } \\
\text { mm (in.) }\end{array}$ & $\begin{array}{c}\text { Air } \\
\text { content, } \%\end{array}$ & $\begin{array}{l}\text { Placement } \\
\text { temperature, } \\
{ }^{\circ} \mathrm{C}\left({ }^{\circ} \mathrm{F}\right)\end{array}$ & $\begin{array}{l}\text { Blaine fineness, } \\
\mathrm{cm}^{2} / \mathrm{g}\left(\text { in. }^{2} / \mathrm{lb}\right)\end{array}$ \\
\hline Pedestal & $298(502)$ & 107 (180) & $166(279)$ & 1045 (1762) & 688 (1160) & $110(4.3)$ & 7.0 & $23(74)$ & $3988(1.36)$ \\
\hline $\begin{array}{l}\text { T-shaped bent } \\
\text { cap }\end{array}$ & 243 (409) & $86(145.5)$ & $154(260)$ & 1039 (1752) & 803 (1354) & $125(5.0)$ & 6.5 & $29(85)$ & 3988 (1.36) \\
\hline $\begin{array}{l}\text { Rectangular } \\
\text { bent cap }\end{array}$ & $251(423)$ & 63 (107) & $126(212)$ & 1108 (1868) & 758 (1277) & 75 (3.0) & 5.5 & $18(65)$ & $3635(1.24)$ \\
\hline Dolphin & $253(426)$ & $100(168)$ & $123(208)$ & $1112(1874)$ & 687 (1158) & $190(7.5)$ & 9.0 & $20(68)$ & $3808(1.30)$ \\
\hline Footing 1 & $313(528)$ & 80 (135) & $157(265)$ & $1035(1745)$ & 643 (1084) & - & - & $22(72)$ & $3988(1.36)$ \\
\hline Footing 2 & $251(423)$ & 63 (107) & $132(223)$ & $1035(1745)$ & $842(1420)$ & $100(4.0)$ & 5.25 & $20(68)$ & $3988(1.36)$ \\
\hline Column 1 & $251(423)$ & 63 (107) & $132(223)$ & $1035(1745)$ & $842(1420)$ & $140(5.5)$ & 6.5 & $23(73)$ & $3988(1.36)$ \\
\hline Column 2 & $251(423)$ & 63 (107) & $132(223)$ & 1035 (1745) & 847 (1427) & $180(7.0)$ & 5.5 & $23(73)$ & $3988(1.36)$ \\
\hline
\end{tabular}

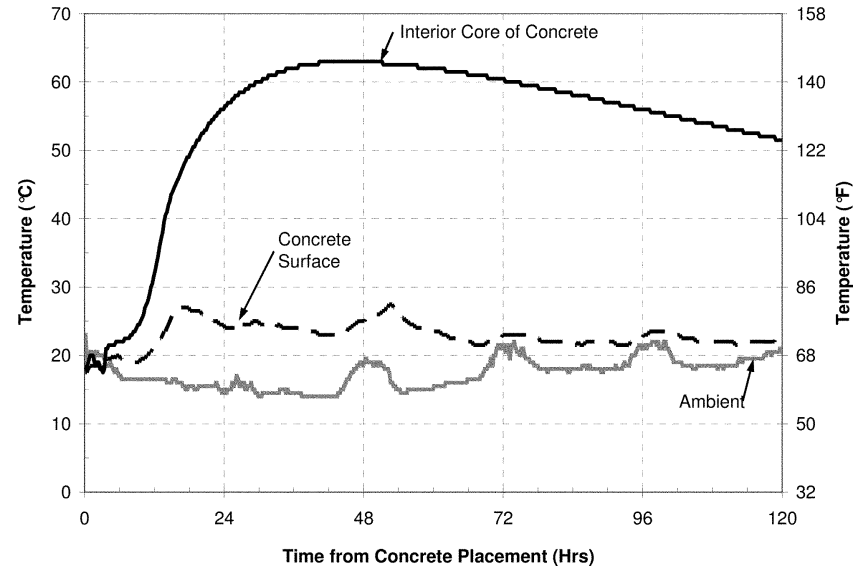

Fig. 1-Concrete core, surface, and ambient temperature data measured for dolphin.

cap, and pedestal were built with wood forms. The rest of the concrete members were constructed with steel forms.

Table 2 shows the concrete mixture proportions and concrete properties. The water content includes all mixing water added, aggregate moisture above the saturated surfacedry condition, and ice. Air-entraining admixtures were used in all concrete mixtures. Normal water reducers were used in all concrete mixtures. Additionally, a mid-range water reducer was used in the dolphin concrete mixture. Crushed granite coarse aggregate was used in the rectangular bent cap project's concrete mixture, siliceous river gravel was used in the dolphin project's concrete mixture, and crushed limestone was used in the remaining concrete mixtures. Natural river sand was used in all concrete mixtures except the rectangular bent cap project's mixture, which contained crushed granite sand. An ASTM C 618 Class C fly ash ${ }^{18}$ was used in the rectangular bent cap project's mixture, and an ASTM C 618 Class F fly ash ${ }^{18}$ was used in the rest of the concrete mixtures. ASTM Type I/II cement ${ }^{16}$ was used in all concrete mixtures.

Figure 1 shows the temperatures recorded for the interior core, concrete surface temperature, and ambient temperature for the dolphin. The recorded core temperatures are very similar in behavior to those recorded in the other concrete members. The difference between the temperature recorded on the outside of the dolphin and the ambient temperature is typical for values recorded next to steel formwork. Figure 2 shows the dolphin being instrumented and during concrete placement.
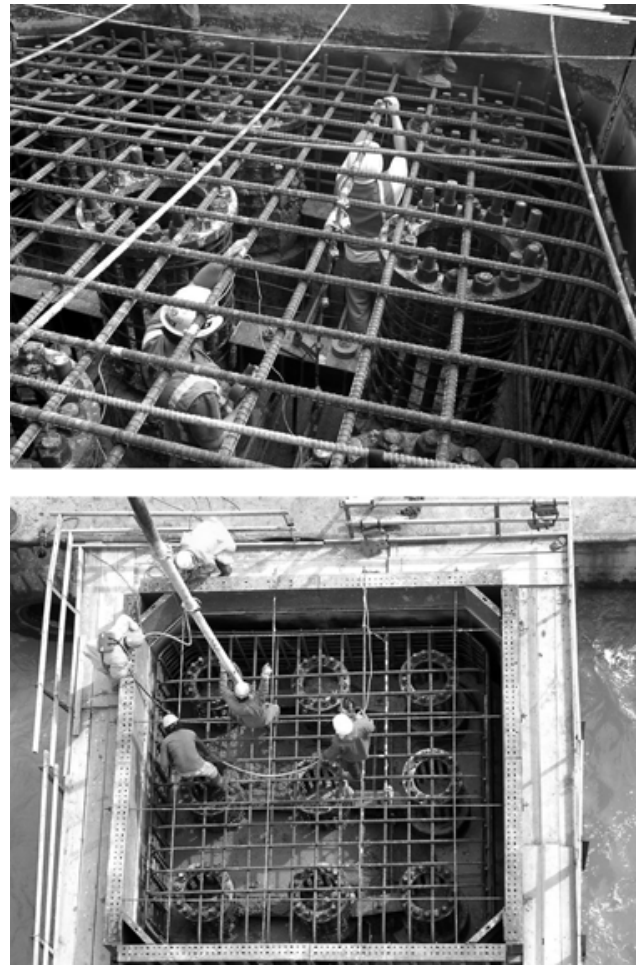

Fig. 2-Dolphin during instrumentation and placement.

\section{Instrumentation}

Weather data during construction of the mass concrete members were collected using a weather station. Temperature and relative humidity data were collected using a probe with a radiation shield. Solar radiation data were collected using a silicon pyranometer. Wind speed and direction data were collected using a wind monitor. The weather station was programmed to measure and record data every hour for each of the field sites.

Temperature sensors with an internal data logger were used for temperature instrumentation. ${ }^{19}$ Each concrete member was instrumented with multiple temperature sensors at various depths and locations in the concrete members. To allow for fast and accurate installation of the temperature sensors in the concrete members, modified temperature sensors were pretaped onto cut pieces of $12 \mathrm{~mm}(1 / 2 \mathrm{in}$.) diameter acrylic dowels or steel reinforcing bars. The prefabricated temperature bars were installed before concrete placement. The location of each temperature bar was selected to capture 
the concrete temperature at the core, within $50 \mathrm{~mm}$ ( 2 in.) of the outermost edge of the member, and at various points in between.

\section{TEMPERATURE PREDICTION METHODS PCA Method}

The PCA Method was used to calculate temperatures for all eight of the instrumented mass concrete members. Some of the members, however, did not meet the conditions prescribed by the PCA Method. The pedestal, T-shaped bent cap, and rectangular bent cap did not meet the size requirements specified in the PCA Method. The T-shaped bent cap, rectangular bent cap, Footing 2, Column 1, and Column 2 did not meet the cement content requirements as specified in the PCA Method. The heat contribution of supplementary cementing materials was assumed to be $50 \%$ of cement, as per the recommendation in section 5.3.2 of ACI 207.1 ${ }^{5}$ (Eq. (2)).

\section{Graphical method of ACI 207.2R}

The graphical method of ACI 207.2R for temperature analysis was performed for all mass concrete members instrumented. The volume-to-surface ratio of the concrete member was calculated assuming that every $25 \mathrm{~mm}$ (1 in.) thickness of wood forms was equal to $0.51 \mathrm{~m} \mathrm{(20} \mathrm{in.)} \mathrm{of}$ concrete, as recommended in Section 2.6 of ACI 207.2R. ${ }^{6}$ Form-liners were treated in a similar manner and were assumed to be equal to $0.51 \mathrm{~m}$ (20 in.) of concrete per $25 \mathrm{~mm}$ (1 in.) thickness of form-liner. Because of the large amount of rigid polyurethane foam used for architectural detailing in the T-shaped bent cap, all surfaces next to the foam were treated as an unexposed surface in the "volume to exposed surface area" calculations. When the fine aggregate was a different type of material than the coarse aggregate, the concrete thermal diffusivity was calculated as shown in Eq. (6) ${ }^{20}$

$$
h^{2}=\frac{\left(h_{c}^{2} \cdot W_{c}+h_{f}^{2} \cdot W_{f}\right)}{\left(W_{c}+W_{f}\right)}
$$

where $h^{2}$ is the weighted concrete diffusivity, in $\mathrm{m}^{2} / \mathrm{h} ; h_{c}{ }^{2}$ is the concrete diffusivity assuming the concrete is made from the coarse aggregate mineral type, in $\mathrm{m}^{2} / \mathrm{h} ; h_{f}^{2}$ is the concrete diffusivity assuming the concrete is made from just the fine aggregate mineral type, in $\mathrm{m}^{2} / \mathrm{h} ; W_{c}$ is the weight of coarse aggregate per cubic meter of concrete, in $\mathrm{kg} / \mathrm{m}^{3}$; and $W_{f}$ is the weight of fine aggregate per cubic meter of concrete, in $\mathrm{kg} / \mathrm{m}^{3}$. Values used in the calculations were manually extracted from charts within ACI 207.2R $\mathrm{R}^{6}$ (Charts 2.1, 2.2, 2.4, 2.5, and 2.6). Cement fineness values were tested using the air permeability method (Blaine) as described in ASTM C 204. ${ }^{21}$ Because Wagner Turbidimeter values are rarely available, equivalent fineness values to the Wagner Turbidimeter Method (ASTM C 115) ${ }^{22}$ were estimated from the Blaine fineness values using Eq. (7) ${ }^{23}$

$$
S_{W}=S_{B} \cdot 0.56
$$

where $S_{W}$ is the Wagner specific surface, ${ }^{22}$ and $S_{B}$ is the Blaine specific surface, ${ }^{21}$ in $\mathrm{m}^{2} / \mathrm{kg}$. Maximum placement temperatures were calculated with and without adjustments for cement fineness.

\section{Schmidt Method}

All eight concrete members were modeled using the Schmidt Method, as detailed in ACI 207.1R. ${ }^{5}$ The columns were idealized as rectangular in all calculations, with little loss in accuracy expected. An inherent problem in using this method is that boundary conditions are very difficult to model. On the surface boundaries, solar radiation and convection need to be accounted for in the analysis. ${ }^{24}$ This was accomplished by using ambient temperature, wind speed, and solar radiation values that were measured onsite during construction. The convection coefficient was calculated using Eq. (8) ${ }^{25}$

$$
\begin{aligned}
h_{c} & =c \cdot 0.2782 \cdot\left[\frac{T_{\infty}-T_{s}}{2}+17.8\right]^{-0.181} \\
& \cdot\left[\left|T_{\infty}-T_{s}\right|\right]^{0.266} \cdot[1+2.8566 \cdot w]^{0.5}
\end{aligned}
$$

where $c=10.15$ for a bottom horizontal surface hotter than ambient or a top horizontal surface cooler than ambient; $c=15.89$ for vertical surfaces; and $c=20.40$ for a bottom horizontal surface cooler than ambient or a top horizontal surface hotter than ambient, where $c$ is a constant; $T_{\infty}$ is the ambient temperature, in ${ }^{\circ} \mathrm{C} ; T_{s}$ is the surface temperature, in ${ }^{\circ} \mathrm{C}$; $w$ is the wind speed, in $\mathrm{m} / \mathrm{s}$; and $h_{c}$ is the convection coefficient, in $\mathrm{W} / \mathrm{m}^{2} / \mathrm{K}$. A solar absorptivity value of 0.3 was used for curing blankets, 0.2 for plywood, ${ }^{26}$ and 0.6 for concrete. ${ }^{27}$ A solar absorptivity value of 0.2 was used for steel forms to account for the shading provided by the horizontal stiffeners of the forms.

At the boundary with the ground, constant temperatures were assumed in the ground at a depth equal to one half the height of the member as shown in Example 6 within ACI 207.1R. ${ }^{5}$ The temperature of the ground at the interface with the concrete was increased by a value assumed to be equal to half of the temperature increase in the concrete, as is done in Example 6 of ACI 207.1R ${ }^{5}$.

The dolphin, pedestal, Footing 1, and Footing 2 were analyzed in one dimension using the Schmidt Method. The rectangular bent cap, T-shaped bent cap, Column 1, and Column 2 were analyzed using two-dimensional heat transfer. The concrete equivalent thickness for the wood formwork, form liners, and cure blanket were assumed equal to the node spacing used. A thickness equal to the node spacing resulted in calculated concrete edge temperatures that were similar to the measured concrete edge temperatures. The temperature rise for the concrete members was manually extracted using the Type I cement curve from Chart 5.3.1 in ACI $207.1 \mathrm{R}^{5}$ because the figure did not have a heat rise curve for Type I/II cement. Temperature-rise values were scaled using the ratio of a calculated 3-day temperature rise to the 3-day temperature rise extracted from Fig. 5.3.1 in ACI $207.1 \mathrm{R}^{5}$. The 3 -day temperature rise was then calculated using Eq. (9)

$$
T_{c r}=\frac{H_{i} \cdot W_{c}}{C_{p} \cdot W_{t}}
$$

where $T_{c r}$ is the calculated temperature rise, in ${ }^{\circ} \mathrm{C} ; H_{i}$ is the 3-day isothermal heat of hydration, in cal/g; $W_{c}$ is the weight of cement per cubic meter of concrete, in $\mathrm{kg} / \mathrm{m}^{3} ; W_{t}$ is the 
Table 3-Maximum recorded and calculated temperatures for concrete members

\begin{tabular}{c|c|c|c|c|c|c}
\hline \multirow{2}{*}{ Member } & \multicolumn{5}{|c}{ Maximum concrete temperature, ${ }^{\circ} \mathrm{C}\left({ }^{\circ} \mathrm{F}\right)$} \\
\cline { 2 - 7 } & Measured & $\begin{array}{c}\text { PCA Method } \\
\text { using Eq. }(1)\end{array}$ & $\begin{array}{c}\text { ACI 207.2R method } \\
\text { not corrected for fineness }\end{array}$ & $\begin{array}{c}\text { ACI 207.2R method } \\
\text { corrected for fineness }\end{array}$ & $\begin{array}{c}\text { Schmidt Method } \\
\text { Pechmidt Method with } \\
\text { calorimetry }\end{array}$ \\
\hline Pedestal & $74.0(165.2)$ & $65.4(149.8)$ & $57.6(135.7)$ & $64.7(148.5)$ & $59.0(138.1)$ & $71.4(160.6)$ \\
\hline T-shaped bent cap & $67.5(153.5)$ & $63.4(146.2)$ & $54.6(130.2)$ & $64.4(148.0)$ & $62.6(144.7)$ & $72.0(161.6)$ \\
\hline Rectangular bent cap & $53.5(128.3)$ & $52.2(126.0)$ & $36.3(97.4)$ & $39.9(103.7)$ & $53.7(128.6)$ & $56.9(134.4)$ \\
\hline Dolphin & $63.0(145.4)$ & $56.3(133.3)$ & $37.6(99.7)$ & $42.0(107.7)$ & $61.5(142.8)$ & $66.7(152.0)$ \\
\hline Footing 1 & $72.0(161.6)$ & $64.6(148.2)$ & $55.6(132.0)$ & $62.1(143.9)$ & $69.3(156.7)$ & $78.0(172.3)$ \\
\hline Footing 2 & $56.5(133.7)$ & $53.9(129.0)$ & $52.9(127.3)$ & $57.4(135.3)$ & $49.6(121.3)$ & $59.2(138.5)$ \\
\hline Column 1 & $58.0(136.4)$ & $56.7(134.0)$ & $48.9(120.0)$ & $54.0(129.2)$ & $56.8(134.1)$ & $57.8(136.1)$ \\
\hline Column 2 & $58.0(136.4)$ & $56.7(134.0)$ & $50.2(122.4)$ & $55.5(131.8)$ & $56.2(133.1)$ & $59.2(138.6)$ \\
\hline
\end{tabular}

Table 4-Time from concrete placement to peak temperature

\begin{tabular}{c|c|c|c|c}
\hline \multirow{2}{*}{ Member } & \multicolumn{4}{|c}{ Time to peak temperature, hours } \\
\cline { 2 - 5 } & Measured & $\begin{array}{c}\text { ACI 207.2R } \\
\text { method corrected } \\
\text { for fineness }\end{array}$ & $\begin{array}{c}\text { Schmidt } \\
\text { Schmidt } \\
\text { Method }\end{array}$ & $\begin{array}{c}\text { Method with } \\
\text { calorimetry } \\
\text { results }\end{array}$ \\
\hline Pedestal & 37 & 31 & 98 & 58 \\
\hline T-shaped bent cap & 36 & 18 & 41 & 50 \\
\hline Rectangular bent cap & 23 & 36 & 43 & 43 \\
\hline Dolphin & 41 & 24 & 77 & 50 \\
\hline Footing 1 & 50 & 38 & 79 & 77 \\
\hline Footing 2 & 48 & 70 & 82 & 58 \\
\hline Column 1 & 47 & 26 & 91 & 70 \\
\hline Column 2 & 59 & 26 & 91 & 82 \\
\hline
\end{tabular}

total concrete weight per cubic meter, in $\mathrm{kg} / \mathrm{m}^{3}$; and $C_{p}$ is the specific heat of the concrete, in $\mathrm{cal} / \mathrm{g} /{ }^{\circ} \mathrm{C}$. Values for $H_{i}$ were obtained experimentally using a isothermal calorimeter at $23{ }^{\circ} \mathrm{C}\left(73{ }^{\circ} \mathrm{F}\right)$. The isothermal tests were performed using cement for each concrete member collected at the batch plant. The cementitious materials in the isothermal tests for the rectangular bent cap and dolphin were tested using the fly ash as a cement replacement (by mass). The isothermal tests for the remaining members were done with only the cement. The fly ash for those members was accounted for by assuming a 50\% cement equivalent as discussed in the graphical method of ACI 207.2R. The adiabatic temperature development curve was also adjusted for placement temperature using Fig. 2.3 of ACI 207.2R. ${ }^{6}$ The calculations used in determining the adiabatic temperature-rise scale factor are shown in Table A-1 in Appendix A.

The concrete temperatures were also calculated using the adiabatic temperature development for each concrete mixture calculated from semi-adiabatic calorimetry tests. The calorimeter consisted of an insulated 55 gallon steel drum that uses a $152 \times 304 \mathrm{~mm}(6 \times 12$ in.) cylindrical concrete sample. Probes were used to record the concrete temperature, heat loss through the calorimeter wall, and air temperature surrounding the test setup. The heat loss through the calorimeter was determined by a calibration test performed by using heated water. Once the concrete was batched, a 152 × $304 \mathrm{~mm}(6 \times 12$ in.) cylinder was made and placed in the calorimeter. Each test was performed over a period of approximately 7 days. Semi-adiabatic calorimetry was performed on concrete sampled from the concrete delivered at the job site. The results from this analysis are referred to in this paper as the "Schmidt Method using calorimetry."

The adiabatic temperature development of each member was also calculated. This was done by adding the adiabatic

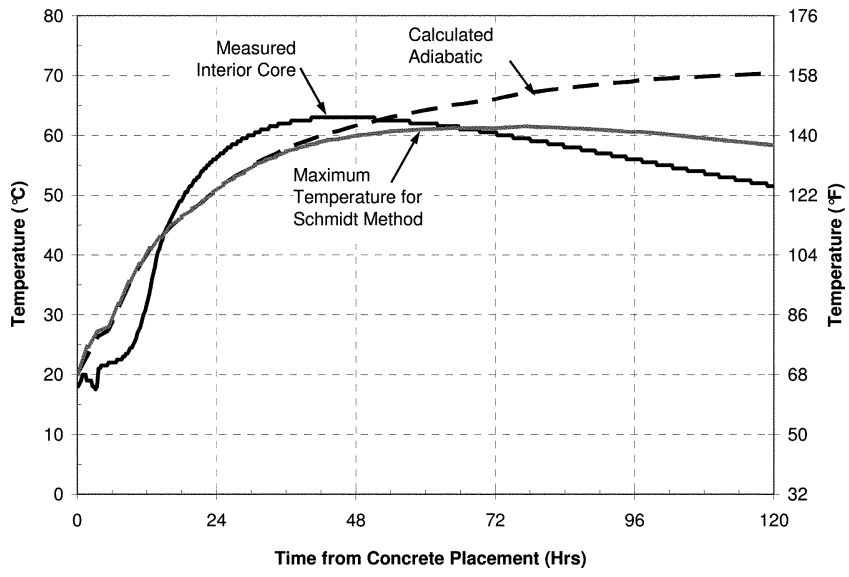

Fig. 3-Recorded core temperature, calculated maximum temperature using Schmidt Method, and calculated adiabatic development for dolphin.

temperature rise curve for each concrete member to the placement temperature. The adiabatic temperature development was calculated, for reference, to evaluate the magnitude of the heat transferred from the concrete core. The validity of the conduction heat transfer can be gauged from results obtained by comparing the predicted concrete core temperature to the predicted adiabatic temperature.

\section{RESULTS AND DISCUSSION}

All of the instrumented mass concrete members showed high temperature increases at the core. Table 3 shows the recorded and calculated maximum temperatures for the eight concrete members. Table 4 shows the measured time to the peak temperature, the calculated time to the peak temperature using the graphical method of ACI 207.2R, and the Schmidt Method.

Figure 3 shows the recorded core temperature, the calculated adiabatic temperature, and the calculated maximum temperature for the dolphin using the Schmidt Method. The shape of the predicted maximum temperature and adiabatic temperature development curves for the dolphin were similar to those of most of the other members. Figure 4 shows the recorded core temperature, the calculated adiabatic temperature, and the calculated maximum temperature for the T-shaped bent cap using the Schmidt Method, which were slightly different from the dolphin.

\section{PCA Method}

As seen in Table 3, the PCA Method ${ }^{4}$ predicted reasonably well the maximum temperature of the rectangular bent cap, Footing 2, Column 1, Column 2, and the T-shaped bent cap, 
in spite of the fact that these members did not meet all of the requirements for the model as discussed in the previous section. This method significantly underpredicted the maximum temperature in the other four concrete members. For example, the difference in measured and predicted maximum temperatures for Column 3 was almost $9{ }^{\circ} \mathrm{C}\left(16^{\circ} \mathrm{F}\right)$, an error of $12 \%$. Interestingly, the PCA Method worked best with the five of the members that did not fully meet this method's assumptions. Results from this comparison demonstrate that the PCA Method is generally not accurate enough to be a reliable predictor of maximum temperature for mass concrete structures. This method is generally not robust enough to be used in temperature control plans for mass concrete members. This method, however, is a useful tool for quick estimates to show the effect of cement content on heat development.

\section{Graphical method of $\mathrm{ACl}$ 207.2R}

The graphical method found in ACI 207.2R $\mathrm{R}^{6}$ underestimated the maximum temperature in the absence of corrections for cement fineness. This method did slightly better when corrections were made for fineness, but the reliability of the method is still quite poor. This method performed the worst with the large members that exhibited an appreciable temperature increase. In the dolphin, for example, the temperature was underestimated by more than $21^{\circ} \mathrm{C}\left(38^{\circ} \mathrm{F}\right)$, an error of $33 \%$. This method also provided a poor prediction of the time when the maximum concrete temperature was reached. This is because cements have changed significantly since the charts in ACI $207.2 \mathrm{R}^{6}$ were developed. Both the rate of heat generation and total heat-generating capacity of cements are now very different than the behavior shown in ACI 207.2R.

\section{Schmidt Method}

The two main components of the Schmidt Method are the heat transfer component and the heat generation component. The heat transfer component performed satisfactorily. The heat generation component performed better when the measured adiabatic temperature development was used. For example, the calculated maximum temperature in the pedestal was underestimated by $20 \%$ when the calculated adiabatic temperature development curve was used and was underestimated by only $3 \%$ when the measured adiabatic temperature development was used. Furthermore, the time to maximum temperature was overestimated by $165 \%$ in the pedestal, whereas it was overestimated by $55 \%$ when the measured adiabatic temperature development curve was used.

The Schmidt Method of conductive heat transfer performed satisfactorily based on the amount of concrete core heat loss when compared to the adiabatic condition. By comparing the adiabatic temperature rise curve to the core concrete temperatures, the core heat loss could be determined. The rate of calculated heat loss in the concrete core was as expected for mass concrete. The Schmidt Method assumes that all nodes have the same thermal diffusivity value. This is why it is necessary to convert formwork and insulation properties to equivalent concrete thickness values. This method also assumes constant values of thermal diffusivity for every node. The thermal conductivity, however, and specific heat have been shown to decrease with increasing degree of hydration. The specific heat of concrete also increases with an increase in temperature. ${ }^{26}$

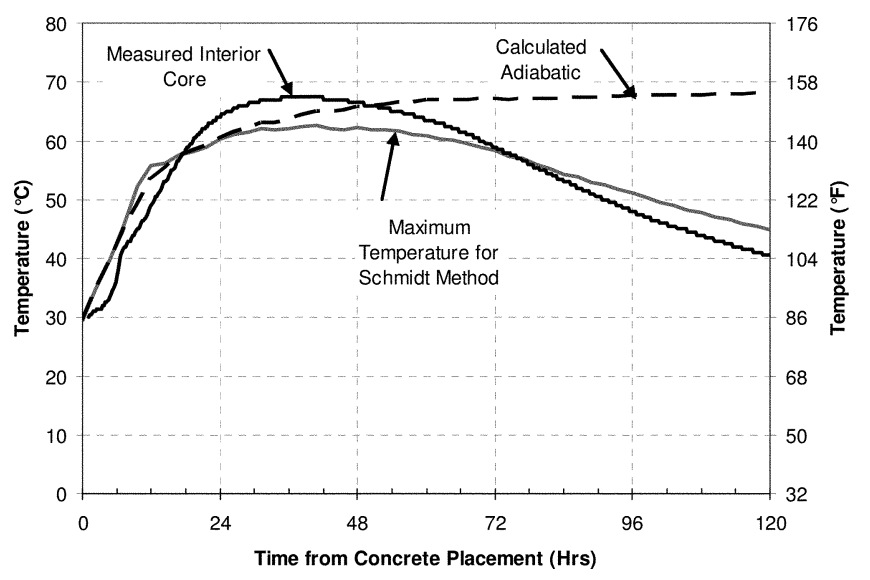

Fig. 4-Recorded core temperature, calculated maximum temperature using Schmidt Method, and calculated adiabatic development for T-shaped bent cap.

The maximum temperature reached in mass concrete bridge members can be more sensitive to the effect of its boundary conditions than large mass concrete. For example, solar radiation values in excess of $900 \mathrm{~W} / \mathrm{m}^{2}$ were recorded for the rectangular bent cap. This dramatically increased the formwork and insulating blanket temperatures. Because of these effects, manual calculation made by using the Schmidt Method should only be performed by an experienced engineer or by using calibrated software.

The heat generation component of the Schmidt Method was enhanced by using semi-adiabatic calorimetry results. Adiabatic temperature curves can be adequate for massive dams where there is little heat loss and the concrete is placed at roughly the same temperature. For smaller mass concrete members, however, some heat loss or gain from the environment may occur. Because cement hydration is temperaturedependent, a change in the temperature will result in deviation from the adiabatic temperature development curve. If the member is small, and heat is lost, the heat generation rate will be significantly different from the adiabatic curve. This may explain why the Schmidt Method tended to underpredict the maximum temperature reached when the adiabatic temperature development curve was used. It may also help explain the tendency to overpredict the maximum temperature reached when the measured adiabatic temperature development is used. A different method that includes the cement temperature dependency could be used to improve the heat generation component of the calculations. Van Breugel ${ }^{28}$ found that the degree of hydration should be used as a basis for all temperature calculations.

The rate of heat generation is critical in determining the temperature rise in mass concrete. A comparison of the maximum temperature recorded versus the calculated adiabatic temperature rise in Fig. 3 and 4 shows how the heat generation rate can significantly change the shape of the maximum temperature curve and the time to peak temperature. The measured maximum temperature curve tends to be a lower, flatter curve, even though the adiabatic temperature eventually reaches that of the concrete member temperature. The calculated time to peak temperature is also considerably larger than the recorded values. This is because a significant amount of heat can be lost while the heat generation rate slows down considerably after 24 to 72 hours. The time to maximum temperature and the time spent at elevated temperatures are 
critical parameters in predicting the possibility of DEF occurrence $^{1}$ and thermal shock susceptibility.

The Schmidt Method makes many assumptions regarding the rate of heat generation. Any method that does not use measured calorimetry curves will not take into account any retardation from chemical admixtures. ACI $207.1 \mathrm{R}^{5}$ recommends neglecting rate changes from chemical admixtures for preliminary calculations because they only affect the temperature increase during the first few hours. For large mass concrete, this assumption may be true. For mass concrete bridge members, the contribution of chemical admixtures to the heat generation rate should not be ignored. slag cement, fly ash, and other SCMs can affect the rate of hydration. A correct determination of the temperature rise during the first few hours is critical to the accuracy of the analysis when the peak temperature can be reached within as little as 24 hours.

Fly ash can significantly change not only the magnitude of the adiabatic temperature rise, but also the rate of heat generation. Calcium oxide content has been shown to be a major indicator of the fly ash heat of hydration. ${ }^{26}$ Further research should be directed at creating a database of continuous heat of hydration development curves for different combinations of cements, supplementary cementing materials, and chemical admixtures.

\section{CONCLUSIONS}

The maximum concrete temperature, maximum concrete temperature difference, time, and duration of the maximum temperature difference all considerably affect the performance of a mass concrete bridge member. The time of the maximum temperature difference is also critical. Based on the work documented in this paper, the following conclusions can be made:

1. The maximum error in predicting the maximum temperature from the PCA Method compared to the measured concrete core temperature for all concrete members examined was $12 \%$. The PCA Method of mass concrete temperature prediction, however, offered no information on the time that the maximum temperature was reached, limiting the usefulness of the method. The criteria for using the method are so narrow that many bridge substructure concrete members do not satisfy the assumptions of the method;

2. The graphical method of temperature prediction found in ACI 207.2R did not produce reliable results for the bridge substructure concrete members discussed in this paper. Both the predicted peak temperature and the predicted time to peak temperature did not compare well to recorded concrete temperatures with errors in some cases of more than 33\%;

3. The Schmidt Method adequately models the conductive heat transfer in the bridge substructure concrete members discussed in this paper, as long as one uses surface boundary assumptions that account for conditions that include the effects of convection and solar radiation. Future numerical heat transfer methods should include corrections for the changes in the concrete thermal conductivity and specific heat as the concrete hardens. The peak temperature reached in mass concrete can be sensitive to the boundary conditions. Results will be improved when convection and solar radiation are fully accounted for in the modeling process;

4. The heat generation component of the Schmidt Method performed better when measured adiabatic temperature development curves were used as compared to when calculated temperature developments obtained from generic charts were used. The time to peak temperature predictions could be very different than predicted, with errors on the order of $165 \%$. Temperatures predicted using this method could be significantly improved by accounting for the heat generated in the concrete by more current hydration models that can account for the effect of modern cements and various SCMs; and

5. Future research should develop a database of adiabatic temperature rise curves using common combinations of various cements, supplementary cementing materials, and chemical admixtures.

\section{ACKNOWLEDGMENTS}

The authors wish to express their gratitude to the Texas Department of Transportation for funding this work and other on-going research. The advice and support of R. Browne, T. Yarbrough, and R. Crowson are greatly appreciated.

\section{REFERENCES}

1. Day, R. L., "The Effect of Secondary Ettringite Formation on the Durability of Concrete: A Literature Analysis," Research and Development Bulletin RD108T, Portland Cement Association, Skokie, Ill., 1992, pp. 59, 83-84.

2. Chini, A. R.; Muszynski, L. C.; Acquaye, L.; and Tarkhan, S., "Determination of the Maximum Placement and Curing Temperatures in Mass Concrete to Avoid Durability Problems and DEF," Final Report, University of Florida, Gainsville, Fla., July 2003, pp. 46-64.

3. Texas Department of Transportation, "Specification 420," June-July 2004, pp. 494-527.

4. Kosmatka, S. H.; Kerkhoff, B.; and Panarese, W. C., Design and Control of Concrete Mixtures, 14th Edition, Portland Cement Association, Skokie, Ill., 2003, pp. 323-325

5. ACI Committee 207, "Mass Concrete (ACI 207.1R-96)," American Concrete Institute, Farmington Hills, Mich., 1996, pp. 29-37.

6. ACI Committee 207, "Effect of Restraint, Volume Change, and Reinforcement on Cracking in Massive Concrete (ACI 207.2R-95)," American Concrete Institute, Farmington Hills, Mich., 1995, pp. 3-8.

7. Detwiler, R. J.; Gjorv, O. E.; and Kjellsen, K. O., "Pore Structure of Plain Cement Pastes Hydrated at Different Temperature," Cement and Concrete Research, V. 20, No. 6, 1990, pp. 927-933.

8. Gajda, J., and VanGeem, M., "Controlling Temperatures in Mass Concrete," Concrete International, V. 24, No. 1, Jan. 2002, pp. 59-62.

9. Bamforth, P. B., and Price, W. F., "Concreting Deep Lifts and Large Volume Pours," Construction Industry Research and Information Association, London, 1995, pp. 19-24, 45-48.

10. Thomas, M. D. A; Mukherjee, P. K.; Sato, J. A.; and Everitt, M. F., "Effect of Fly Ash Composition on Thermal Cracking in Concrete," Fly Ash, Silica Fume, Slag, and Natural Pozzolans in Concrete, Proceedings of the Fifth CANMET/ACI International Conference, SP-153, V. M. Malhotra, ed., American Concrete Institute, Farmington Hills, Mich., V. 1, 1995, pp. 81-98.

11. Bamforth, P. B., "Large Pours," letter to the editor, Concrete, Cement and Concrete Association, Wexham Springs, Slough, England, Feb. 1981, pp. $19-20$.

12. Emborg, M., "Models and Methods for Computation of Thermal Stresses," Prevention of Thermal Cracking in Concrete at Early Ages, RILEM Report 15, R. Springenschmid, ed., E\&FN Spon, London, 1998, pp. 178-230.

13. Mangold, M., and Springenschmid, R., "Why are Temperature Related Criteria so Unreliable for Predicting Thermal Cracking at Early Ages?" Thermal Cracking in Concrete at Early Ages, R. Springenschmid, ed., E\&FN Spon, London, 1994, pp. 361-368.

14. Eberhardt, M.; Lokhorst, S. J.; and Van Breugel, K., "On the Reliability of Temperature Differentials as a Criterion for the Risk of Early-Age Thermal Cracking," Thermal Cracking in Concrete at Early Ages, R. Springenschmid, ed., E\&FN Spon, London, 1994, pp. 353-360.

15. Mangold, M., "Thermal Prestress of Concrete by Surface Cooling," Thermal Cracking in Concrete at Early Ages, R. Springenschmid, ed., E\&FN Spon, London, 1994, pp. 265-272.

16. ASTM C 150, "Standard Specification for Portland Cement," ASTM International, West Conshohocken, Pa., 2004, 8 pp.

17. Schack, A., Industrial Heat Transfer, translated by H. Goldschmidt and E. P. Partridge, John Wiley \& Sons, Inc., London, 1933, pp. 54-56.

18. ASTM C 618, "Standard Specification for Coal Fly Ash and Raw or Calcined Natural Pozzolan for Use in Concrete," ASTM International, West Conshohocken, Pa., 2003, 3 pp. 
19. Ramaiah, S. V.; Dossey, T.; and McCullough, B. F., "An Investigation of the Thermacron ${ }^{\circledR}$ I-button for Early-Age and Long-Term Temperature," TRB 2002 Annual Meeting, 2002, 19 pp. (CD-ROM)

20. ACI Committee 207, "Cooling and Insulating Systems for Mass Concrete (ACI 207.R-93)," American Concrete Institute, Farmington Hills, Mich., 1993, p. 7.

21. ASTM C 204, "Standard Test Method for Fineness of Hydraulic Cement by Air-Permeability Apparatus," ASTM International, West Conshohocken, Pa., 2000, 8 pp.

22. ASTM C 115a, "Standard Test Method for Fineness of Portland Cement by the Turbidimeter,' ASTM International, West Conshohocken, Pa., 2003, 7 pp.

23. Mindess, S.; Young, J. F.; and Darwin, D., Concrete, 2nd Edition, Prentice Hall, Upper Saddle River, N.J., 2003. pp. 47-48.

24. Wojcik, G. S.; Fitzjarrald, D. R.; and Plawsky, J. L., "Modeling the
Interaction Between the Atmosphere and Curing Concrete Bridge Decks with the SLABS Model," Meteorology Applied, V. 10, 2003, pp. 1-22.

25. ASHRAE, 1993-ASHRAE Handbook, American Society of Heating, Refrigerating and Air-Conditioning Engineers, Inc., Atlanta, Ga., 1993, p. 22.17 .

26. Schindler, A. K., "Concrete Hydration, Temperature Development, and Setting at Early Ages," PhD dissertation, University of Texas at Austin, Austin, Tex., 2002, pp. 86-88, 94, 100, 175-179.

27. Incropera, F. P., and Dewitt, D. P., Fundamentals of Heat and Mass Transfer, John Wiley \& Sons, Inc., New York, 2002, p. 931.

28. Van Breugel, K., "Prediction of Temperature Development in Hardening Concrete," Prevention of Thermal Cracking in Concrete at Early Ages, RILEM Report 15, R. Springenschmid, ed., E\&FN Spon, London, 1998 , pp. $178-230$.

\section{APPENDIX A}

Table A-1-Calculations used in determining adiabatic scale rise factor

\begin{tabular}{|c|c|c|c|c|c|c|c|c|}
\hline Item & Pedestal & T-shaped bent cap & Rectangular bent cap & Dolphin & Footing 1 & Footing 2 & Column 1 & Column 2 \\
\hline Specific heat, cal $/ \mathrm{g} /{ }^{\circ} \mathrm{C}^{5}$ & 0.22 & 0.22 & 0.19 & 0.18 & 0.22 & 0.22 & 0.22 & 0.22 \\
\hline Three-day isothermal test, cal/g & 56 & 56 & 65 & 56 & 56 & 56 & 56 & 56 \\
\hline Calculated 3-day temperature rise, ${ }^{\circ} \mathrm{C}\left({ }^{\circ} \mathrm{F}\right)$ & $33(59)$ & $26(48)$ & $48(86)$ & $47(84)$ & $36(64)$ & $27(49)$ & $27(49)$ & $27(49)$ \\
\hline $\begin{array}{l}\text { Type I cement 3-day temperature rise from } \\
\text { Fig. 5.3.1 in ACI } 207.1 \mathrm{R},{ }^{5}{ }^{\circ} \mathrm{C}\left({ }^{\circ} \mathrm{F}\right)\end{array}$ & $31(55)$ & $31(55)$ & $31(55)$ & $31(55)$ & $31(55)$ & $31(55)$ & $31(55)$ & $31(55)$ \\
\hline Total adiabatic temperature rise scale factor & 1.31 & 1.06 & 1.56 & 1.53 & 1.34 & 1.04 & 1.04 & 1.04 \\
\hline
\end{tabular}

